British Journal of Marketing Studies (BJMS)

Vol. 8, Issue 1, pp.68-78, February 2020

Published by ECRTD- UK

Print ISSN: 2053-4043(Print), Online ISSN: 2053-4051(Online)

\title{
SPORTS PRICE AND PROMOTION MANAGEMENT STRATEGIES AMONG FOOTBALL CLUB OPERATORS IN SOUTH-SOUTH NIGERIA
}

\author{
Henry Chidi Maduanusi \\ Department of Human Kinetics and Health Education, Faculty of Education, \\ University of Port Harcourt, Rivers State, Nigeria. \\ Prof. Tamunobelema T. Orunaboka \\ Department of Human Kinetics and Health Education, Faculty of Education, \\ University of Port Harcourt, Rivers State, Nigeria. \\ Dr. Ifeanyichukwu Christian Elendu \\ Department of Human Kinetics and Health Education, Faculty of Education, \\ University of Port Harcourt, Rivers State, Rivers State, Nigeria. \\ Email: dricelendu@yahoo.com
}

\begin{abstract}
The aim of the study is to find out the sports price and promotion management strategies among football club operators in south-south Nigeria. Two research questions guided the study. The descriptive survey design was used for the study. The population for the study was 450 football club operators. All the 450 football club operators constituted the sample. A structured questionnaire was used for data collection. The reliability co-efficient of 0.74 was established through testretest method. The generated data were analyzed using mean and standard deviation for research questions. The findings of the study revealed that, price of sports products is not regulated by a board of committee and price of sports items is not cheap in and around the stadium. Also, corporate and individual sponsors do not engage in partnering football club operators in south-south Nigeria. Based on the findings, it was recommended among others that, football club operators in south-south Nigeria should ensure the provision of quality sports product and services for sports consumers' satisfaction. It was therefore concluded that, football club operators embraced the requirement for consistency in sports price management strategies, and asserted that there is opportunity to get better in the strategies practiced in the art of sports promotion management.
\end{abstract}

KEYWORDS: football club operators, sports consumers, sports price, sports promotion.

\section{INTRODUCTION}

Globally, the term "sports" has different meaning to different people on their own interest of defining the concept. Sports, as defined by Danjuma, (2017) is a social entity that has grown from being just a form of entertainment and recreational activity to assume a professional status. Sports develop individuals, society and nations. It is a 
British Journal of Marketing Studies (BJMS)

Vol. 8, Issue 1, pp.68-78, February 2020

Published by ECRTD- UK

Print ISSN: 2053-4043(Print), Online ISSN: 2053-4051(Online)

big time business venture shaping the social, political and economic constructs of nations, worldwide.

In order for sports to achieve the specific objectives of developing individuals, society and nations, the need for sports marketing mix management strategies. There are a number of these sports marketing mix management strategies, however, for the benefit of this study, sports consumer, sports price management and sports promotion management will be given priority. Sports consumers is an individual or group who use a sport or sport-related product or service in exchange for a direct like cash to buy a ticket to a game or indirect like purchasing a television in which sport is one form of entertainment payment (Aaron and Bob, 2015). Sports consumers' can come in many forms including spectators, sports fans and business sponsors. There is no simple formula to describe how and why sport consumers behave as they do.

Marketing is a process by which companies and sports firms create value for sports consumers and build strong customer relationship with them in order to capture value from them in return (Kotler, 2011). Strategies for marketing mix management among sports club operator's starts and ends with the sports consumer. Sport marketing is the application of marketing concepts to sport products and services, and the marketing of non-sports products through an association with sport. Like other forms of marketing, sport marketing seeks to fulfill the needs and wants of consumers. It achieves this by providing sport services and sport-related products to consumers. However, sport marketing is unlike conventional marketing in that it also has the ability to encourage the consumption of non-sport products and services by association.

Sports marketing mix management strategies are those strategy that are in place which helps to manage the sports marketing mix in other to satisfy sports consumers, this management strategies falls under the $7 \mathrm{ps}$ marketing mix. Consumers of sport services receive benefits in the form of an intangible experience. For instance, sports services are offered in the form of fitness class, entertainment like matches or coaching. These services are not physical objects that can be purchased or moved about. They cannot be stored away for consumers who may wish to buy at a later time (Aaron $\&$ bob, 2015).

The main purpose sports marketing mix management strategies is to put in place an appropriate planning and development of a satisfactory product for a particular market demand and price fixing. Marketing management identifies customers' needs and wants for making profit.Sports marketing is a process of designing and implementing activities for production, pricing, promotion and distribution of product to satisfy the needs of consumers, and to achieve the sports administrator's objectives. The concept of sports marketing is ambiguous in its meaning for both practitioners and academicians. Smith and Stewart (2015) stated that sport marketing is a process of developing relationships between sport brand and consumer, where the main goal is 
British Journal of Marketing Studies (BJMS)

Vol. 8, Issue 1, pp.68-78, February 2020

Published by ECRTD- UK

Print ISSN: 2053-4043(Print), Online ISSN: 2053-4051(Online)

to focus on planning and creating how a sport brand will stand and distribute to the target audience.

There are two types of sport marketing: the first one is marketing of sport and the second one is marketing through sport (Smith \& stewart, 2015). Both of them are focused on collaboration with athletes, where the main goal is to have athletes' endorsement of a particular brand. It was also noted in the literature that the sports marketing process entails the attainment of the marketing goals of sports entities through an effective and efficient manipulation of the marketing sports mix elements (product, price, place, physical evidence, people, and process). Kotler and Armstrong, (2014) define marketing mix as the set of controllable marketing variables that the firm blends to produce the response of wants in the target market. The term marketing mix is described as the result of the innovative efforts and activities of the managers in mixing the pricing, promoting, and distribution of the ideas, goods, and services (Kotler, 2016). The use of marketing mix can be helpful in provision of new suggestion for the market or promotion of the current market strategy (Lovelock \& Wright, 2011). The most common and stable framework of marketing mix is the same mix of "McCarthy" which summarizes the 12 elements of Burdon to the famous 4ps which stands for the words "product", "price", "promotion" and "place". The notion of 4ps is accepted as a principle in different marketing texts (McCarthy cited by Kotler, 2016). However, two are vital to this study which are: Price and promotion.

Marketing management is the art and science of choosing target markets and getting, keeping, and growing customers through creating, delivering, and communicating superior customer value (Kotler, 2016). Generally, marketing mix should have a systemic and. In other words, the good product with a good price, and by the use of good coordinated approach between its components in order to be effective on persuasion of the customer's communicative and advertising methods, is provided to the customer.

Sport pricing is complex and critical to the success of the marketing plan. Nowadays, pricing is not only the most crucial key element in competition by affecting buyer choice as in history, but it also plays an important role in creating customer value, and building customer relationships.Comparing to other tools within marketing mix concept, Price is the amount of money charged for a product or services, or the sum of the value that customers exchange for the benefits of having or using the product or service. In simply term, price is the amount of money that a buyer has to pay for a product or service that he or she purchases (Kotler \& Armstrong 2014).

This is similar with the views of Kotler and Armstrong (2014) price is the only tool which produces revenues while the others represent costs. Mammon, (2012) indicated that among marketing mix elements, product significantly Influences customer satisfaction and also have competitive advantage. Price is one of the ways marketers communicate with customers, it is seen as revenue oriented been the only 
British Journal of Marketing Studies (BJMS)

Vol. 8, Issue 1, pp.68-78, February 2020

Published by ECRTD- UK

Print ISSN: 2053-4043(Print), Online ISSN: 2053-4051(Online)

marketing mix element that produces revenue. The challenge for the sport marketer is to determine the right price for the consumer. The price of a product can be manipulated many ways.

Promotional pricing can be used for tickets to the game o for memberships to the fitness club, or sale prices on sports clothing for during a holiday period, special sale prices on sporting goods equipment for seasonal sports, or price breaks as the quantity purchased increases. There are also long term price planning strategies that the sport marketer can use. However, price is one aspect of the marketing plan that may be readily changed. For example, sport organizations often alter their prices to attract different consumers. Also, for instance, students may pay a different price for event tickets than the general public pays Promotion in sport marketing the word promotion covers a range of interrelated activities. All of these companies need to inform their customers for example about their new product, remind about the great advantage what there exists if they buy it from them and of course persuade in order to close the deal and either create a new customer relationship or strengthen an old one. Promotion is best seen as the way that sport marketers communicate with consumers to inform, persuade and remind them about a product. The aim of promotion is to encourage consumers to develop a favorable opinion about a sport product which is aligned to a predetermined positioning strategy, and then to stimulate consumers to try the sport product.

The modern marketing is more than just having differentiated product, conveniently available to targeted consumers and competitive pricing. Promotion is about communicating and educating consumers. For example, promotion might involve telling potential consumers about a product, reminding them of its benefits or persuading them that it is worth trying. Promotion involves all forms of communication with consumers, not just advertising. A successful product or service does not mean anything unless the benefits can be clearly communicated to the target market, therefore, when firms choose their strategy, they should consider their target market and their behavior (Khan, 2011).

Promotion is one part of the marketing mix that has activities to introduce products and services to the public in order to attract public interest to buy products and then become customers in the future. And advertising that is one part of the promotion activities directly related to the sale so that the impact on corporate profits and corporate value to be achieved. As a go public company, profitability of the entity becomes one of the attractions because it can increases firm value (Harnovinsah \& Alamsyah, 2017).

Availability of quality sports products and services is an essential requirement for sports consumers' satisfaction. Product is anything that can be offered to a market for attention, acquisition, use, or consumption that might satisfy a want or need (Kotler \& Armstrong 2014).Basically, products include tangible such as soccer ball, volleyball 
British Journal of Marketing Studies (BJMS)

Vol. 8, Issue 1, pp.68-78, February 2020

Published by ECRTD- UK

Print ISSN: 2053-4043(Print), Online ISSN: 2053-4051(Online)

net, badminton racket etc. and the other which is intangible includes Services, ideas, coaching. Mixture of these things is also included in products. Mammon, (2012) indicated that among marketing mix elements, product significantly Influences customer satisfaction and also have competitive advantage.

Among the forms of product services are considered more special to pay attention to because of its importance in the world economy. Services consist of activities, benefits, or satisfactions offered for sale that are essentially intangible and do not result in the ownership of anything. Kotler and Armstrong (2013) defined product as anything tangible or intangible offered to a market for attention, use and consumption with aim of satisfying needs and wants of customers. However, the term product can also refer to services, people, places, ideas and the benefits that a sport organization offers consumers. Many sport organizations offer a service, such as a form of physical activity, entertainment or an experience. There is often no physical product to take away, but a sport organization might offer some intangible benefits such as lifestyle, social group or even a belief system. In marketing, the word product means more than a good, service, or idea.

Fairness of the price of sports products and services is a vital strategy that helps the sports marketers and club operators to make profit and also satisfy consumers, the price of every product or services Is the amount of money charged for a product or services, or the sum of the value that customers exchange for the benefits of having or using the product or service. The challenge for the sport marketer is to determine the right price for the consumer. According to Kotler and Armstrong (2014) price is the only tool which produces revenues while the others represent costs. Price is one of the ways marketers communicate with customers, it's seen as revenue oriented been the only marketing mix element that produces revenue. Price is the amount of money charged for a product or services, or the sum of the value that customers exchange for the benefits of having or using the product or service. In simply term, price is the amount of money that a buyer has to pay for a product or service that he or she purchase Kotler and Armstrong (2014).

Sports price management has to do with the techniques employed by sport marketer in making available products to sport consumer based on the market environment. For example, lowering prices during a recession or economic downturn or the team's performance as well as increasing prices as team's performance dramatically improves.Sports promotion management on the other hand involves interrelated activities designed to attract attention and stimulate the interest and awareness of sports consumers, and of course, encourage them to purchase a sport product. Promotion is used because of informing, reminding and persuading (Krishna, Gopala, $\&$ Reddy, 2010). Sports promotion means selling the product marketed through sportsso promotion is everything that sports marketers do in order to attract sports customers and get their products sold. While ordinary consumers may have their preferences, they normally have a choice between several products. Football supporters, however, 
British Journal of Marketing Studies (BJMS)

Vol. 8, Issue 1, pp.68-78, February 2020

Published by ECRTD- UK

Print ISSN: 2053-4043(Print), Online ISSN: 2053-4051(Online)

would rarely change to another club only because the ticket price of the competitor is more reasonable. This is the reason why this study examined the role played by sports price management and sports promotion management marketing mix strategies among football club operators in south-south Nigeria.

\section{Statement of the Problem}

In the whole of Nigeria, the south-south geo-political zone is a football loving region of the country that has been involved in the operation of football clubs for years; however there are still lapses in the aspect of satisfying sports consumers, especially in marketing mix management of football clubs. It has been observed so many inadequacies that come up prior to and during football events. Practices such as, discrepancies between prices of available sports products and the average purchasing power of the average person in the environment of a football venue as well as low turn-out of football club fans and residents of such environment within the south-south region of Nigeria. What bothered the researcher is to determine how sports price management and sports promotion management could serve as strategies for marketing mix management among football club operators in south-south Nigeria.

\section{Aim and Objectives of the Study}

This study investigated sports price management strategies among football club operators in south-south Nigeria. Specifically, the objectives were to:

1. Establish the sports price management strategies adopted by football club operators in south-south Nigeria.

2. Determine the sports promotion management strategies adopted by football club operators in south-south Nigeria.

\section{Research Questions}

1. What are the sports price management strategies adopted by football club operators in south-south Nigeria?

2. What are the sports promotion management strategies adopted by football club operators in south-south Nigeria?

\section{METHODOLOGY}

\section{Research Design}

Descriptive survey design was adopted for the study, Elendu, (2010) noted that descriptive survey design investigates studies, describes events, behavior as they occur in their natural settings at a particular time. The study investigated, evaluated, observed the strategies for marketing mix management among football club operators in south-south Nigeria. 
British Journal of Marketing Studies (BJMS)

Vol. 8, Issue 1, pp.68-78, February 2020

Published by ECRTD- UK

Print ISSN: 2053-4043(Print), Online ISSN: 2053-4051(Online)

\begin{tabular}{|c|c|c|}
\hline $\mathbf{S} / \mathbf{N}$ & CLUB OPERATORS & POPULATION \\
\hline 1 & Head Coaches & 6 \\
\hline 2 & Assistant Coaches & 12 \\
\hline 3 & Fitness Trainers & 30 \\
\hline 4 & Kits and Equipment Managers & 14 \\
\hline 5 & Managers & 12 \\
\hline 6 & Secretaries & 15 \\
\hline 7 & Welfare Officers & 45 \\
\hline 8 & Media crews & 12 \\
\hline 9 & Chairmen & 12 \\
\hline 10 & Players & 250 \\
\hline 11 & Medical Teams & 30 \\
\hline \multirow[t]{2}{*}{12} & Supporters group chairmen & 12 \\
\hline & Total & 450 \\
\hline
\end{tabular}

\section{Sample and Sampling Technique}

The sample size of the study is 450 football club operators. The entire population was used for the study because the population is manageable and relatively small. This is in line with Elendu, (2010) who explained that it is appropriate to study the entire population, when the population to be studied is small and manageable.

\section{Instrument for Data Collection}

A self-structured and developed questionnaire was used for data collection. The questionnaire contain introductory statement and instruction on purpose of the instrument and how to fill the questionnaire, this instrument is be made up of two (2) sections, section A demographic data such as years of football experience, level of education, age, Gender and marital status. While section B contains information on the strategies for marketing mix management among football club operators in southsouth Nigeria. The questionnaire are modified four point Likert-type on a four point rating of Strongly Agree (SA) Agree (A) Disagree(D) and Strongly Disagree (SD) the point was weighted thus SA(4points) A (3points) D (2points) SD (1point).

\section{Validity of the Instrument}

In order to ensure the face and content validity of the research instrument, the draft of the questionnaire was presented to the researcher's supervisors and three (3) other experts in the Department of Human Kinetics and Health Education, University of Port Harcourt, Rivers State. Their comments, suggestions and contributions were considered in producing the final draft of the questionnaire.

\section{Reliability of the Instrument}

Test-retest method was used to establish co-efficient of 0.74 . Each of the variable subscale reliability co-efficient is as follows: price (0.71) and promotion (0.77). The researcher administered the validated instrument to Twenty (20) sports club operators 
British Journal of Marketing Studies (BJMS)

Vol. 8, Issue 1, pp.68-78, February 2020

Published by ECRTD- UK

Print ISSN: 2053-4043(Print), Online ISSN: 2053-4051(Online)

in (Anambra State) south-eastern part of Nigeria. After two weeks interval the same questionnaire re-administered to same respondents.

\section{Method of Data Collection}

The researchers administered the copies of the questionnaire to the respondents. A total number of four hundred and fifty (450) copies of questionnaire were administered but four hundred and thirty nine (439) were correctly filled and returned. This translated into $(98 \%)$ return rate.

\section{Method of Data Analysis}

The completed copies of the questionnaire were collated, coded and analyzed using statistical package for social sciences (SPSS) version 21. The descriptive statistics of mean and standard deviation were used for research questions

\section{RESULTS}

Research Question 1: What are the sports price management strategies adopted by football club operators in south-south Nigeria?

Table 1: Sports price management strategies adopted by football club operators in south-south Nigeria $(n=439)$.

\begin{tabular}{lllllll}
\hline S/N & Statements & $\overline{\mathbf{X}}$ & SD & \multicolumn{2}{c}{ Remark } & \\
\hline 1 & $\begin{array}{l}\text { Sports consumers pays for price of sports items } \\
\text { at installment. }\end{array}$ & 2.74 & 1.08 & strategy & \\
2 & $\begin{array}{l}\text { The price of sports product is lowered to ensure } \\
\text { consumers satisfaction. }\end{array}$ & 2.00 & 1.08 & $\begin{array}{l}\text { Not } \\
\text { strategy }\end{array}$ & a \\
3 & $\begin{array}{l}\text { The price of sports products is regulated by a } \\
\text { board of committee. }\end{array}$ & 2.33 & 1.16 & $\begin{array}{l}\text { Not } \\
\text { strategy }\end{array}$ & a \\
& $\begin{array}{l}\text { The price of sports items is cheap in and around } \\
\text { the stadium. } \\
\text { Grand mean }\end{array}$ & 1.81 & 1.04 & $\begin{array}{l}\text { Not } \\
\text { strategy }\end{array}$ & a \\
& & $\mathbf{2 . 2 2}$ & $\mathbf{1 . 0 0}$ & & \\
\hline
\end{tabular}

Result in Table 1 indicated that all the items had mean scores below the criterion mean score of 2.50 except item 1 from the responses of the football club operators. The low mean score of 2.00, 2.33 and 1.81 shows that the respondents disagreed that the price of sports product is lowered to ensure consumers satisfaction; price of sports products is regulated by a board of committee and price of sports items is cheap in and around the stadium. This fact is supported by their grand mean of 2.22 below the criterion mean. This indicated that sports price management strategies are not adopted by sports club operators in south-south Nigeria.

Research Question 2: What are the sports promotion management strategies adopted by football club operators in south-south Nigeria? 
British Journal of Marketing Studies (BJMS)

Vol. 8, Issue 1, pp.68-78, February 2020

Published by ECRTD- UK

Print ISSN: 2053-4043(Print), Online ISSN: 2053-4051(Online)

Table 2: Sports promotion management strategies adopted by football club operators in south-south Nigeria $(n=439)$.

\begin{tabular}{llllll}
\hline $\mathbf{S} / \mathbf{N}$ & Statements & $\overline{\mathbf{x}}$ & SD & Remark \\
\hline 1 & $\begin{array}{l}\text { Different football programs are provided for the } \\
\text { consumers. }\end{array}$ & 2.48 & 0.96 & Not a strategy \\
2 & $\begin{array}{l}\text { Sports product and services are advertised in the print } \\
\text { media. }\end{array}$ & 2.82 & 0.98 & strategy \\
3 & $\begin{array}{l}\text { Corporate and individual sponsors are engaged in sports. } \\
\text { Grand mean }\end{array}$ & 2.02 & 1.01 & Not a strategy \\
& & & & \\
\end{tabular}

The result in Table 2 indicated that respondents disagreed that different football programs are provided for the consumers and corporate and individual sponsors rarely engaged in sports with mean scores of 2.48 , and 2.02 respectively. Conversely, they agreed that Sports product and services are advertised in the print media. The grand mean of 2.44, means that some of the sports promotion management strategies are not adopted by sports club operators in south-south Nigeria.

\section{SUMMARY OF FINDINGS}

1. It showed that, the respondents agreed that price of sports products is not regulated by a board of committee and price of sports items is not cheap in and around the stadium.

2. It revealed that, the respondents disagreed that different football programs are provided for the consumers and corporate and individual sponsors do not engaged in sports.

\section{DISCUSSION OF FINDINGS}

The findings that price of sports products is not regulated by a board of committee and price of sports items is not cheap in and around the stadium are not strategies adopted by club operators. This is these are strategies that are likely to attract spectators and possibly win more fans to cubs. The findings that different football programs are provided for the consumers and corporate and individual sponsors do not engaged in sports are not strategies used by football club operators is not expected since sports sponsorship is one of the globally acknowledged promotional tools. The findings are in agreement with Charumbira (2014) who reported that the Zimbabwean sports federations are using inappropriate and ineffective sports marketing strategies.

\section{CONCLUSION}

Based on the findings of the study, football club operators embraced the requirement for consistency in sports price management strategies, and asserted that there is opportunity to get better in the strategies practiced in the art of sports promotion 
British Journal of Marketing Studies (BJMS)

Vol. 8, Issue 1, pp.68-78, February 2020

Published by ECRTD- UK

Print ISSN: 2053-4043(Print), Online ISSN: 2053-4051(Online)

management regardless of the duration of football experience, status of academic experience and type of football club operators in south-south Nigeria.

\section{Recommendations}

Based on the findings and conclusion of the study, it was recommended that:

1. Football club operators should ensure that the sports price is regulated for affordability by the sports consumers.

2. Football club operators should involve individual and corporate organizations in sponsoring football programmes in South-south Nigeria.

3. Different football programs should beconsumers.

4. Sponsors should be encouraged to sponsor sports programmes.

5. Provison of cheap sports items without comprising for quality.

\section{References}

Aaron, C.T \& Bob, S (2015). Introduction to sports marketing, Routledge Ltd publishers 2nd edition.

Charumbira L. T. (2014). The effectiveness of the sports marketing strategies used by Zimbabwean Collegiate sports federations. International Journal of Marketing and Business Communication, 3(3\&4), $66-75$.

Danjuma, M. M (2017). Administrative determinants of students' sports participation in Nigeria. Department of Human Kinetics and Health Education, Adekunle Ajasin University, Akungba- Akoko, Nigeria

Elendu, I. C. (2010). Fundamentals of research and statistics for student in human kinetics and other educational discipline. Port Harcourt: The Glory of the House Publishing company.

Harnovinsah, A \& Sustari.(2017). The mediation influence of value relevance of accounting information, investment decision and devidend policy on the relationship between profitability and the company's value. Journal Akuntansi, 21.

Isaac, T. A. (2016). An empirical study of marketing mix as a satisfaction tool in modern sport administration in Ghana

Khan, S. (2011). Marketing mix strategy adaptation: A retail organization's response to global economic downturns. Cape Town, South Africa

Kotler, P. \& Armstrong, G. (2013). Principles of marketing. (14th ed). Edinburgh Gate Harlow Essex, England. Pearson Education

Kotler, P. \& Armstrong, G. (2014). Principles of marketing: global edition. 15th ed. Pearson Education Limited

Kotler, P. \& Keller, K. L. (2016). Marketing management. (15th global ed.) Harlow: Pearson Education Limited

Krishna, D. S. Gopala, H. V. S \& Reddy, P. N. (2010). Services management. Mumbai: Global Media.

Lovelock, C., \& Wright, L. (2011). Principles of marketing and services. Translation by Abolfazl Tajzadeh Namin, Q3. Tehran: Publication of the Side 
British Journal of Marketing Studies (BJMS)

Vol. 8, Issue 1, pp.68-78, February 2020

Published by ECRTD- UK

Print ISSN: 2053-4043(Print), Online ISSN: 2053-4051(Online)

Mamoun, N. A. (2012). An empirical model of marketing strategy and shareholder value: A value-based marketing perspective. An International Business Journal incorporating Journal of Global Competitiveness, 22(1), 48-89

Mojtaba, M. B. M \& Ali D (2018). The effects of 7P marketing mix components on sporting goods customer satisfaction. International Journal of Business and Management Invention (IJBMI)

Smith, A. C.T. \& Stewart, B. (2015). Introduction to sport marketing. New York: Routledge 